\title{
Chapter 11 \\ Improving Opportunity Through Better Human Capital Investments for the Labor Market
}

\author{
Harry J. Holzer
}

\begin{abstract}
While education levels in the U.S. have risen in recent years, students from disadvantaged backgrounds have fallen behind other Americans in college attainment amid increasing college dropout rates. The causes of this growing gap include weaker academic preparation in their K-12 years (and earlier); lower wealth and liquidity that make it harder to pay tuition and other costs; worse information about and lower familiarity with higher education; and pressure to work full-time while being enrolled to help support their families. In addition, disadvantaged college students are heavily concentrated in weaker and under-resourced institutions such as community colleges, which generate fewer graduates. Even when students gain credentials like associate degrees, the degrees often do not have strong labor market value because of students' poor labor market information and the weak incentives of public institutions to respond to the labor market by creating more classes in high-demand fields. And high-quality career and technical education opportunities in the U.S., such as "sectoral" training and work-based learning, have not been developed to the extent possible to provide students a wider range of pathways to careers from which to choose. Efforts to improve these outcomes must therefore focus on three goals: (1) improving completion rates at our public colleges by strengthening student supports; (2) expanding postsecondary options, at the bachelor's level or below, that have labor market value; and (3) developing additional pathways to good-paying jobs through work-based learning and high-quality career and technical education, beginning in secondary schools.
\end{abstract}

\footnotetext{
This chapter was initially prepared as a paper for the conference on Opportunity in America, sponsored by the Educational and Testing Service (ETS) in Princeton, NJ, on December 9-10, 2014. The author thanks Greg Duncan, Richard Murnane, and David Neumark for very helpful comments.
}

H.J. Holzer $(\bowtie)$

McCourt School of Public Policy, Georgetown University, Washington, DC, USA

American Institutes for Research, Washington, DC, USA

I. Kirsch, H. Braun (eds.), The Dynamics of Opportunity in America,

DOI 10.1007/978-3-319-25991-8_11 
Keywords Human capital $\bullet$ Labor market $\bullet$ Economic opportunity $\bullet$ Educational opportunity $\bullet$ Educational attainment $\bullet$ Career and technical education (CTE) • Apprenticeship $\bullet$ Career academies $\bullet$ Career pathways $\bullet$ Sectoral training $\bullet$ Worker skills • Dropout prevention • Two-year colleges • Four-year colleges

\section{Introduction}

Since about 1980, labor market inequality has increased quite dramatically in the United States. Gaps in earnings between highly educated workers-such as those with college diplomas or graduate degrees - and those without them have roughly doubled in magnitude. The high labor market "return" to education creates strong incentives for workers to invest in various kinds of "human capital," such as higher education degrees. Indeed, attaining some type of college credential is perhaps the strongest predictor of upward mobility for young people from low-income families, both across generations or within them, so the incentives for the poor to invest in higher education should be as strong as, or even stronger, than for anyone else.

It is therefore somewhat surprising that, during much of the past 35 years, the growth of higher education credentials among young Americans has been quite modest, especially among those from lower- and middle-income families, while gaps in higher educational attainment between children from poor and nonpoor families have actually grown wider during this period. Though there has been a surge in postsecondary educational attainment among young Americans since 2000, and especially since the Great Recession began in 2007, poor children continue to lag behind in such attainment, and earnings gaps between college graduates and others remain very high.

In this chapter I review the factors that limit postsecondary skills attainment among low-income students. I argue that, although the incentives are very strong for poor students to obtain these degrees, a range of personal and institutional barriers as well as market failures often prevent them from doing so.

To improve economic opportunity in the job market, we must therefore enhance the ability of low-income students to obtain college degrees and other credentials that reflect skills that are valued in the labor market. I will argue for a range of policies and practices that should improve the odds that poor young people attain some type of college credential—such as a bachelor's (B.A.) degree and higher, an associate (A.A.) degree, or an occupational certificate. I will also argue that improving a range of other skill-building pathways for poor students-including high-quality career and technical education; various models of work-based learning, such as apprenticeship; and other approaches, such as career pathways and training in particular employment sectors (sectoral training) —-would improve their opportunities in the labor market as well. 


\section{Investing in Human Capital: Why Does Postsecondary Educational Attainment Lag behind for the Poor?}

\section{Theory and Evidence}

The theory of human capital investment, as developed by Gary Becker (1996), Jacob Mincer (1974) and others, posits that (all else equal) a rise in labor market returns to any particular skill, or an educational credential that signals the attainment of that skill, should generate higher investments in that skill or credential. So if demand for those with higher education rises in the labor market, and the earnings premium for having a college diploma (relative to high school) increases, more students will enroll in college and obtain that degree. This increase in the supply of college graduates should, in turn, reach a point that it offsets the higher demand and causes the earnings premium to fall to its earlier level.

Of course, this scenario assumes no other complications in the adjustment process, including market failures of any kind, and no other limits on the potential supply of skilled labor. If, for example, there are lags in the time needed for such skill development, then the adjustment process might take many years to complete, and in the presence of imperfect information and foresight among students, the supply of skilled workers over time could potentially overshoot the new equilibrium, causing wages of skilled workers to oscillate, as they have in some markets for highly educated workers (Freeman 1971).

On the other hand, the ability of students to make these additional investments at all might be limited-if, for example, the marginal students in these markets have lower scholastic ability, their information about market returns is incomplete, or they face higher costs of investing in the skills. Indeed, among low-income students, it is quite possible that all of these complications could limit their investment decisions over time. ${ }^{1}$

If the theoretical responses of investments in skills to market increases in pay premia for those skills are therefore somewhat ambiguous, what does the empirical evidence show? The important and well-known book by Claudia Goldin and Lawrence Katz, The Race between Education and Technology (2008), offers us perhaps the clearest long-term evidence on this issue. They show that, due to technological developments in a variety of industries, the labor market return to high school diplomas rose sharply in the early part of the twentieth century, and in response, the supply of high school graduate labor rose over the first several decades of the century, just as predicted by the human capital model.

Indeed, the process continued until the higher wage premium associated with high school graduation had disappeared by mid-century. Goldin and Katz note that the rise in high school enrollments and graduation reflected not only private

\footnotetext{
${ }^{1}$ This discussion assumes that the market return to a completed degree is at least as high for the disadvantaged as for other students, which appears to be the case (Backes, Holzer, and Velez 2014).
} 
investment decisions but also a major public policy response to increase the teaching capacities of public high schools and encourage (or require) more such enrollments. ${ }^{2}$

In the last few decades of the twentieth century, a similar process occurred in which technological change (plus globalization and other institutional forces) likely increased the demand for college graduates and caused their relative wages to rise as well. ${ }^{3}$ But, unlike the earlier episode, there was relatively little rise in the supply of highly skilled workers until the end of the century. Though Autor (2014) notes that higher enrollments in college finally increased the supply of highly educated labor after the year 2000, and especially after the onset of the Great Recession in 2007, this increase was sufficient only to stabilize the premium associated with college rather than reduce it. ${ }^{4}$

Furthermore, Bailey and Dynarski (2011) have shown that the response of college enrollments and attainments to the higher college wage premiums of the 1980s and 1990s varied strongly by family income, with higher responses among highincome students than lower-income ones. Accordingly, the gap in B.A. attainments that already existed by family income grew larger over time. Other evidence (e.g., Holzer and Dunlop 2013) also showed rising enrollments in A.A. programs among poorer students and minorities after 2000, while Whites/nonpoor students showed greater increases in B.A. enrollments and attainments, thus contributing to widening earnings gaps as well.

\section{Explaining the Rising Attainment Gaps among Disadvantaged Students}

What accounts for the rising gap in educational attainment between disadvantaged and other students in the past 30 years?

Importantly, we must distinguish enrollment rates in higher education from completion rates among those who enroll. The data show quite large increases in enrollments over time among the poor and minorities as well as nonpoor and/or White

\footnotetext{
${ }^{2}$ Mandatory high school enrollment up to a certain age (usually 16) in most states was a mechanism by which higher high school enrollment was required.

${ }^{3}$ College enrollments and supply actually rose substantially in the late 1960s and early 1970s in response to the Vietnam War because college students were deferred from being drafted; this caused the college wage premium to decline substantially in the 1970s (Freeman 1976). But enrollments declined after the war ended, and the positive shift in labor demand for college graduates appears to have begun around 1980. The associated rise in the college premium was not sufficient to dramatically raise the supply of such graduates for the next few decades. Labor economists have long debated the extent to which the rising college premiums of this period mostly reflect labor demand and supply factors (Goldin and Katz 2008); (Autor et al. 2008) or other institutional forces like weaker unions and lower statutory minimum wages (Card and Dinardo 2007).

${ }^{4}$ By most accounts, real wages did not rise for college or high school graduates after 2000, only rising for those with graduate degrees beyond the B.A. (e.g., Mishel et al. 2012-2013).
} 
students. Indeed, some evidence suggests that enrollment rates have come close to converging across these groups, conditional on graduating from high school. And, since high school graduation rates have improved markedly for the poor in the past few decades (Murnane 2013), and certain high school reforms show great success in improving the access of the poor and minorities to college enrollment (Bloom and Unterman 2014), college enrollment rates among minorities and the poor should continue to grow over time. Even among the dwindling numbers of high school dropouts, college enrollment options might also grow among those who obtain a GED as the preparation and tests that determine receipt of this degree grow more rigorous over time. ${ }^{5}$

But college completion rates among enrollees have worsened over time (Bound et al. 2009), with large gaps evident by race and family income, especially at fouryear colleges and universities (Holzer and Dunlop 2013). For instance, Holzer and Dunlop show that completion rates at four-year colleges and universities (within approximately 8 years of graduating from high school) average over $60 \%$ for the entire population but just over $30 \%$ for disadvantaged students. ${ }^{6}$ At A.A. programs in two-year colleges, completion rates are more comparable across these groups (at about $35 \%$ ) but are generally low for all students, and the concentration of disadvantaged or minority young people is much higher at these schools than for middleclass students or Whites. ${ }^{7}$

What accounts for these gaps? The research by Bound, Lovenheim, and Turner and others shows that a number of factors contribute to lower college completion rates among the disadvantaged. These include:

- weaker academic preparation in the K-12 years;

- lower wealth and associated liquidity constraints limiting ability to pay tuition and other college expenses;

- worse information about and lower familiarity with higher education; and

- pressure to support a family by working full-time during enrollment.

If anything, the gaps in earlier academic achievement, and therefore preparation for college, across family income groups have also grown over time (though they have fallen somewhat by race-Magnuson and Waldfogel 2008; Reardon 2011), thus contributing to differences in their educational outcomes. But, even within

\footnotetext{
${ }^{5}$ The effects of the more traditional GED on college attainment or earnings appeared to be modest at best (Murnane and Tyler 2000; Heckman et al. 2010). Those who pass the newer, more rigorous one will likely show greater impacts on these outcomes, though we do not yet know if pass rates will decline.

${ }^{6}$ Disadvantaged students in this study refer to those from the bottom quarter of the socioeconomic status distribution, which presumably measures longer-term family income better than annual income. The data on completion are derived from the 2000 panel of the National Educational Longitudinal Survey (NELS).

${ }^{7}$ Completion rates are somewhat higher if measured for those in certificate as well as A.A. programs at two-year colleges, though the average wages they generate are lower. On the other hand, completion rates calculated for community college enrollment populations that include adults and not just a cohort of youth out of high school are usually much lower than $35 \%$.
} 
groups of students with fairly uniform achievement levels, large gaps in completion rates between poor and other students are observed (Backes et al. 2014).

What role is played by the rising costs of higher education in America (College Board 2013b)? If capital markets operated fully efficiently, academically able students from low-income families would be able to fully borrow for whatever human capital investments they were capable of making. But evidence has shown that accumulated family wealth (especially through the housing market) and access to financial aid have some impact on student enrollment and attainment (Lovenheim 2011; Brown et al. 2009), thus suggesting that capital markets are highly imperfect in overcoming wealth differences across families and lack of access to liquid wealth (often known as "liquidity constraints") among the disadvantaged. ${ }^{8}$ And, as the financial costs of two- and four-year public institutions continue to rise, because of reductions in state financial assistance to these institutions (College Board 2013b), these constraints may grow more serious over time.

It is also clear that information about the world of higher education is highly imperfect, especially among first-generation college enrollees from disadvantaged families. Indeed, when applying to college, low-income students are much more likely to attend the two- or four-year colleges located closest to where they live, which (for poorer and minority students) are likely lower-tier public colleges; as a result, there is often some significant undermatching between high-achieving students from low-income families and the colleges they attend (Bowen et al. 2005, 2009). Such undermatching appears to at least partly reflect differences in information about school quality available to the disadvantaged compared to other students, as well as in the likelihood of being accepted to higher-quality schools. ${ }^{9}$ Accordingly, fairly small increments in information on higher education can have sizable effects not only on whether such students enroll but also where (Goodman 2013; Hoxby and Turner 2014), while assistance with filling out financial aid forms can have a significant impact as well (Bettinger et al. 2012).

Also, full-time work, and therefore part-time enrollment, is strongly associated with lower completion rates (College Board 2013a); this pressure to work is no doubt especially strong among single parents of small children. And a greater lack of social capital and supports among such students likely impedes their ability to successfully complete classes and accumulate credits as well.

\footnotetext{
${ }^{8}$ In perfect capital markets, high-ability students should have no difficulty borrowing the funds needed to cover the costs of investing in college, as such investments should be regarded by the markets as relatively safe and generating a strong return. But very imperfect information about student ability or other factors reduces the funding available for investments in higher education; this, in turn, forces students to rely more heavily on their own family income or wealth, which causes many from lower-income or lower-wealth families to be "liquidity constrained." It is also likely that disadvantaged students choose to rely less heavily on loans, the repayment and debt servicing of which might be more burdensome to, and impose more risk on, those with lower incomes (unless repayment were fully income-contingent).

${ }^{9}$ Undermatching could, of course, also reflect personal preferences if disadvantaged students might feel more out of place at more elite schools socially or worry about the higher costs of attending.
} 
On top of these personal factors, the institutions they attend matter as well (Bound et al. 2009). Even controlling for K-12 achievement, students who attend four-year colleges have much higher completion rates than those at two-year colleges, as we noted above, and within the former group, completion rates rise with college quality. In other words, given groups of students are more likely to graduate when they attend elite private colleges and universities, as well as the flagship state universities, than when they attend less selective public colleges. And it is in the less selective colleges and universities that much of the recent increases in college enrollments have occurred. Thus, raising the access of lower-income youth to fourinstead of two-year colleges, and to more selective ones within the former, might actually raise their graduation rates. ${ }^{10}$

Why do completion rates vary by institution? For one thing, the elite colleges have much more resources per student and can provide a range of academic and personal supports that cannot be matched at less selective schools. They also provide other benefits to students struggling to finish their degree programs. For instance, the more affluent schools can afford more sections of courses, thus enabling more students to fit them into their schedules; at the less selective schools, more rigid scheduling makes it harder for students to complete their chosen programs - especially if the students are working full time. The higher quality of the student peer groups at the more selective schools likely also contributes to these effects (Sacerdote 2001).

Even within institutions, finishing a program depends on what supports are available to students and also to their chosen fields of study. The data tell us that, all else equal, those majoring in science, technology, engineering or math (STEM) have somewhat lower completion rates, as the level and difficulty of work required in STEM classes is higher and requires greater levels of earlier math preparation (Backes et al. 2014).

But, perhaps more surprisingly, the harder fields of study are not always the ones with the lowest completion rates. Using administrative data from the state of Florida, Backes, Holzer, and Velez find the lowest completion rates in both two- and fouryear colleges among those majoring in fairly nondescript humanities fields like "general studies" or "liberal studies." And large subsets of students end up in these fields, especially in A.A. degree programs and among disadvantaged students. ${ }^{11}$ Rates of completion are also higher in more technical certificate programs than in A.A. programs, perhaps partly because the former are completed much more quickly.

\footnotetext{
${ }^{10}$ This argument, of course, runs counter to the one frequently made that affirmative action actually hurts the educational attainment of minorities by enabling them to attend school where they are too disadvantaged academically to succeed. The evidence in support of this claim does not appear persuasive (Holzer and Neumark 2006).

${ }^{11}$ In the Florida data, $55 \%$ of students in A.A. programs overall major in the humanities, usually reflecting "general studies" or "liberal studies," while for disadvantaged students (defined here as those eligible for free or reduced-price lunch) the comparable fraction is $60 \%$.
} 
Another type of institution is the for-profit colleges, which have recently grown in size and now consume quite large fractions of federal student aid. ${ }^{12}$ Recent analysis (Cellini 2012; Deming et al. 2013) shows lower completion rates in the for-profit schools, somewhat lower earnings among those who complete them, and higher debt burdens among those who do not complete them.

\section{What About Earnings?}

Ultimately, the institution of higher education that one attends, the field of study one chooses, and the degree that one does or does not complete all have important effects on one's future earnings.

As is widely known, the average labor market returns to the B.A. degree (relative to a high school diploma) have roughly doubled since 1980, and now those with B.A.'s earn nearly $80 \%$ more than high school graduates (Autor 2014). For those who have continued beyond the B.A. and completed some type of graduate degree, returns have grown even more substantially; this has occurred even in the past decade or so, when the returns to the B.A. have flattened (as enrollments and attainment of the B.A. have risen).

Returns to the A.A. degree have also risen over time, especially for females, though not by as much as those for B.A. degrees and higher (Kane and Rouse 1995; Acemoglu and Autor 2010; Bailey and Belfield 2013). ${ }^{13}$ But vocational certificates can generate important earnings gains for low-income students as well and take much less time to complete than A.A. or B.A. degrees. In fact, those with certificates in high-demand or technical fields - such as health care or advanced manufacturing-frequently earn more than those with A.A.'s (and even some with B.A.'s) in humanities or "liberal studies," though less than those with more technical A.A. degrees (Backes et al. 2014). ${ }^{14}$ More generally, the field of study one chooses has very large effects on earnings, implying that the average return to a particular academic credential can be somewhat misleading about any particular individual's true prospects.

\footnotetext{
${ }^{12}$ For instance, over a quarter of Pell financial aid now goes to students at for-profit schools (College Board 2013b).

${ }^{13}$ To infer changing returns over time, the estimated returns to community college in Bailey and Belfield can be compared to those estimated earlier in Kane and Rouse, though the data and samples used differ somewhat between the two studies. Acemoglu and Autor (2010) use consistent data and sampling methods over time, but they only list years of schooling completed rather than the A.A. degree. One can roughly infer the changing returns to the A.A. degree over time in their work by looking at returns for those with 14 years of schooling.

${ }^{14}$ Carnevale et al. (2011) and Owen and Sawhill (2013) also emphasize the high variance in returns across fields and the fact that the earnings of some certificate or A.A. degree holders can exceed those of B.A. holders at the lower end of the B.A. distribution.
} 
For those who do not complete their degree programs, there is still some return in the form of higher earnings to credits attained. But those who drop out of twoand four-year college programs often do so before they have attained many credits, in addition to losing the "sheepskin effect" of completing and attaining the degree. This is especially true for those with poor academic preparation in the K-12 years, who often need remediation when they attend community colleges and cannot take many courses for credit until they have successfully completed these remedial programs (Bettinger et al. 2013; Long 2014).

All of this implies that many college-going students from disadvantaged families will ultimately enjoy much less economic success than the average earnings of college graduates imply. Too many of them will go to A.A. programs or less selective four-year colleges where completion rates in general are low; once there, some will likely be trapped in non-credit-bearing remediation classes from which they cannot emerge. Others will choose fields of study at these institutions with even lowerthan-average completion rates and low labor market compensation. And many will drop out before having accumulated enough credits to gain much compensation, even in fields that the labor market does value.

Besides the weak academic preparation that many of these students bring to college, and the generally low resources of the institutions they attend, are there other problems which lead to the discouraging outcomes we've described? I believe there are problems of too little information and too weak incentives at the community colleges and other public four-year colleges and universities.

Most students get virtually no career (or even academic) counseling before or during college; most never obtain any workforce services of the type routinely provided in a jobs (or "one-stop") center financed by the U.S. Department of Labor. Indeed, the student experience at most two-year colleges has been described by one prominent researcher as a "shapeless river" in which students float along but receive little structure or guidance, and little assistance even while navigating across programs (Scott-Clayton 2011; Jenkins and Cho 2012). This stands in sharp contrast to some traditional proprietary vocational colleges (Rosenbaum 2002), where coursetaking and curricula are very structured and job placement assistance is strong. Though some studies (Wiswall and Zafar 2013; Long et al. 2014) show that new information on the labor market has just limited influence on student choices, it seems likely that these effects would be greater among the disadvantaged (whose choices right now seem to reflect so little attention to market returns). ${ }^{15}$

But, even if student choices were better informed and therefore more optimal, they would be constrained by limited teaching capacity in high-demand fields and other institutional features that are common at two-year colleges and the less prestigious four-year programs where resources are very limited. Because instructors

\footnotetext{
${ }^{15}$ Altonji et al. (2012) reviews the literature on choices of student major and emphasizes how early choices about studying certain fields (like math and science), often made under great uncertainty about the future, constrain later choices of major in response to labor market developments.
} 
and equipment are frequently more expensive in the high-demand fields, and because subsidies from most states are still based primarily on student "seat time," regardless of academic or subsequent labor market success; college administrators have little incentive to expand instructional capacity in these high-cost fields (Holzer 2014). ${ }^{16}$

\section{Are There Other Pathways to Labor Market Success Besides College?}

One of the reasons that returns to college have grown so much in the U.S. is that those for a high school diploma have diminished, especially for young men. Indeed, most American employers have little reason to believe that the average high school graduate brings occupational or technical skills to the workplace that they will value, or strong communication or analytical skills, or even strong basic cognitive ones. Indeed, on a recent test of skills among workers in 24 Organisation for Economic Co-operation and Development (OECD) countries, Americans scored quite low on literacy or problem-solving proficiency and especially on numeracy; this was especially true among those without postsecondary education. And the skills of non-college-going high school graduates have diminished in recent years as college enrollment rates have risen, so the pool of non-college-going high school graduates looks relatively worse over time. ${ }^{17}$

Yet in other European countries like Germany, employers are willing to pay high school graduates more, at least partly because they know these young people will bring some analytical and technical skills to jobs that they value. The same seems much less true in the U.S. today.

For students who might not be bound for college or universities right away, especially right after high school, a range of other approaches to enhance their labor market skills are being developed and implemented in a number of states and localities. These include high-quality career and technical education programs in high school, work-based learning models like apprenticeships, and innovative approaches to adult training like sectoral models. We consider each of these approaches below.

\footnotetext{
${ }^{16}$ While Rosenbaum's (2001) study argues that proprietary occupational colleges more successfully link their students to the labor market than do community colleges, the recent evidence on the broader category of proprietary (or for-profit) colleges has been less positive (Deming et al. 2013). ${ }^{17}$ See OECD (2013) for results from a new cross-national evaluation of adult literacy known as PIAAC (Programme for the International Assessment of Adult Competencies), which largely confirm earlier findings from the PISA (Programme for International Student Assessment) tests given at earlier ages.
} 


\section{Career and Technical Education}

Traditionally, non-college-bound students, especially those from minority or disadvantaged backgrounds, have enrolled in vocational education in the U.S. or been "tracked" there against their will. These programs prepared students mostly for lowwage jobs, often in declining sectors. Beginning in the 1960s, resentment from minority families and communities over tracking led to declining enrollments in these programs, though they were not reformed for decades. Even when the schoolto-work programs of the 1990s briefly received federal funding (Neumark 2007), traditional vocational programs went largely untouched. And, though their quality has improved somewhat in recent years, career and technical education (CTE) programs have not become a large-scale alternative to academic programs that prepare students for "college only." 18

But a number of newer CTE models have been emerging that no longer force students to choose between college and "career" and instead try to prepare them for both (Holzer et al. 2013). Best known of these programs are the career academies, which are programs within more general high schools that prepare students for careers in a particular sector, such as health care, information technology, or finance. Students take courses within the academy as well as outside of it and often find parttime or summer work within the sector. Evaluation evidence shows strong and lasting impacts on the earnings of enrollees, especially disadvantaged young men, whose earnings remain nearly $20 \%$ higher than those in the control group 8 years after enrollment, at least partly because of the greater labor market exposure that academy students receive (Page 2012). There is also no evidence of lasting effects (positive or negative) on high school completion or college enrollment (Kemple 2008). More recent versions of career academies put more emphasis on maintaining strong college preparatory curricula while still maintaining the emphasis on specific sectors and careers.

Other models, perhaps less well known or less rigorously evaluated, also try to prepare students for both college and careers. These include the High Schools that Work in many Southern states; Linked Learning in California; and high-tech high schools (Holzer et al. 2013). High school programs that provide strong career-based instruction and a seamless entry into college (especially the kinds of "early college high schools" reviewed in Schwartz and Hoffman 2014) look particularly promising. Virtually all students at these schools get some career exposure and exploration. Wherever possible, high-quality academic material is incorporated into work- or project-based learning to contextualize the material and make it more relevant to students. Links to employers in targeted industries, and professional development

\footnotetext{
${ }^{18}$ Some recent changes have been driven by the latest reauthorization of the Carl T. Perkins Act in 2007, which provides $\$ 1$ billion for state and local CTE programs. The current version of Perkins requires states to identify growing or high-wage "career clusters" and to generate "paths of study" to move students into these sectors. There is also evidence that the extent to which CTE students take math and science courses in high school has risen in recent years. See Holzer et al. 2013.
} 
for staff, is emphasized as well. A network of "pathway states" aims to expand the best models and increase student and school participation in them. ${ }^{19}$

\section{Work-Based Learning}

Work-based learning models, sometimes called "learning while earning," have enjoyed a recent surge of interest, even outside of school CTE programs. These models include internships, co-op programs at colleges, apprenticeships, and "career pathways."

Many such programs provide students with paid work experience as well as a postsecondary credential of value in the labor market (Holzer and Lerman 2014b). At a time when young people are experiencing low employment rates (due to the Great Recession and weak labor market recovery afterward), combining work experience with postsecondary attainment is an appealing option. The paid work experience might better motivate low-income students to complete their training and also contextualizes the learning.

Apprenticeships, in particular, give students strong paid-work experience while they gain an occupational credential. Early on, the wages they receive might be somewhat below market levels so employers don't have to fully bear the cost of such training. ${ }^{20}$ But this means that public sector costs are quite low, while employers also seem to like the program. German companies, in particular, have introduced such programs in the U.S., though not necessarily in identical form to the wellknown apprenticeship model widely used in Germany. ${ }^{21}$

In the U.S., certain states-like South Carolina, Wisconsin, and Georgia-are encouraging employers to expand apprenticeships through marketing campaigns and modest financial incentives to help offset costs (Lerman 2014). Indeed, while employers often find them appealing, few would develop them completely on their own due to a variety of market failures. ${ }^{22}$

Incumbent worker training is another model of work-based learning. A range of states have provided subsidies for such training, at least before the Great Recession began (Hollenbeck 2008). The training was mostly limited to nonprofessional and

\footnotetext{
${ }^{19}$ Much of this work has been based on an influential report entitled Pathways to Prosperity (Symonds et al. 2011). See also Hoffman (2011).

${ }^{20}$ As Becker has pointed out, the more general the training, the less employers will be willing to pay for it, because workers could leave at any time before employers recoup the costs of their investments.

${ }^{21}$ Nelson Schwartz, "Where Factory Apprenticeship is Latest Model from Germany." New York Times, November 27, 2013.

${ }^{22}$ Economists, in particular, often wonder why certain activities that benefit both workers and employers are not undertaken more frequently on their own. A range of market failures, such as high fixed costs for organizing such programs, limited information about their benefits, and wage rigidities (such as the minimum wage) that limit firms' abilities to share training costs with workers, could impede these undertakings.
} 
nonmanagerial starting employees, and the training was usually designed to help them advance within the companies (or to prevent them from being laid off). To prevent the training from being too narrowly focused (or too "customized," in more modern lingo) on the needs of the specific employer, especially when public funds for the training are being provided, the states attempt to ensure that skills are at least somewhat general and "portable" to other employers and sectors. Evidence suggests positive impacts both on workers and on their performance in the workplace (Holzer et al. 1993; Ahlstrand et al. 2003; Hollenbeck 2008.)

\section{Sectoral Training/Career Pathway Programs}

Training outside of the workplace that nonetheless targets jobs in a particular growing or high-wage sector, with the active involvement of particular employers, is known as "sectoral training." Workforce intermediaries bring together employers in that sector, training providers (either community colleges or others) and workers. The intermediaries help provide the workers with access to needed supports and services, including transportation and childcare. The intermediaries also work with providers and employers to make sure that the training fits the employers' needs. If successful, employers come to trust the intermediaries over time to screen workers and refer only those with strong skills and work habits.

Rigorous evaluations (Maguire et al. 2010; Roder and Elliott 2011) have shown that sectoral programs can generate large impacts on the earnings of adults and youth-of $30 \%$ or more-within 2 years of the onset of training. But the training generally works only for disadvantaged workers with quite strong basic skills and job readiness rather than the "hard to employ." Questions also remain about the extent to which impacts survive over time, particularly after workers leave their current jobs and maybe even that sector of employment.

Many states have begun efforts to scale up "sectoral" models by creating partnerships between community colleges and employers or industry associations (National Governors Association 2014). Efforts in many cities and substate regions of the country have been undertaken as well (National Fund for Workforce Solutions 2014). ${ }^{23}$ The Obama administration has also embraced "demand driven" or "job driven" training as ways to meet the needs of the long-term unemployed and other disadvantaged workers. ${ }^{24}$

But little data exists to date measuring the outcomes achieved, in terms of numbers of workers trained or employed in these broader efforts, much less what the

\footnotetext{
${ }^{23}$ The National Fund is an effort funded by several philanthropic foundations to expand and scale sectoral training models at the city or regional level. It currently operates at over 30 sites around the country.

${ }^{24}$ See the White House (2014) for a very recent report by the Office of the Vice President on how to encourage more state and local workforce boards to engage in demand-driven (or "job driven") training.
} 
impacts are on worker earnings. Tensions can sometimes exist between the time it takes to build local or state "partnerships" between employers, intermediaries, and service providers, on the one hand, and the often-changing skill needs of employers and workers in a dynamic labor market on the other. Making sure that these models are not just windfalls for employers who would otherwise provide the training themselves, or that the training serves at least somewhat disadvantaged workerswhom employers might be reluctant to hire-requires some vigilance on the part of intermediaries or state officials.

Finally, a number of states are trying to develop "career pathways" that combine classroom work in a certificate or A.A. program with various amounts of work experience as they move up an occupational ladder of some type. For instance, students might first become a certified nursing assistant and then a licensed practical nurse, with some ultimately becoming registered nurses. A network of states are receiving technical assistance and support for developing a range of these programs (CLASP 2014) within broader career pathway "systems." But little evidence exists to date on the impacts of these efforts (Fein et al. 2013).

\section{Policy Implications}

Based on the preceding discussion, a policy agenda to expand opportunities of disadvantaged Americans to build more labor market skills would include the following goals:

- improve completion rates at two- and four-year colleges;

- expand postsecondary options that have labor market value; and

- develop additional and alternative pathways to skill-building and work experience through expanding high-quality CTE and work-based learning

\section{Improving College Completion Rates}

Perhaps the best thing we could do to improve college completion rates for disadvantaged students would be to improve their academic preparation in the K-12 years. An enormous research and policy literature already exists on this topic, to which I can add relatively little. But it is clear that any such policies need to emphasize both equity and accountability, with more resources going to poor students and communities and strong performance incentives guiding their use. This can be accomplished with stronger curricula (which could be encouraged through widespread implementation of the Common Core and its Next Generation Science Standards), teacher professional development, and incentives based on teacher performance in salary determination, along with higher compensation for strong teachers in math 
and science and in segregated or high-poverty areas ${ }^{25}$ High school reforms that are modeled on successes like the Small Schools of Choice in New York, along with other dropout prevention efforts (Balfanz 2010), would help as well.

Given their K-12 performance, increasing the access of disadvantaged students to better colleges and universities would clearly improve their education and employment outcomes. One way to do so would be to provide better information on college choice to high school students as they prepare to apply for college. The evidence to date indicates that even small and low-cost improvements in disseminating information among such students can improve the quality of the colleges to which they apply (Hoxby and Turner 2014). Merely requiring all students to take the ACT exam can generate more information about college quality for these students, which ultimately increases enrollments at better colleges (Goodman 2013; Hyman 2013). Changes in recruitment practices, with flagship and elite colleges reaching out to more disadvantaged students and/or those in poorer neighborhoods, would help as well.

Once disadvantaged students apply more frequently to better colleges, they might also be given better chances of being accepted in the admissions processthrough some adjustment of the relative weights applied to traditional academic performance measures (like grades and especially standardized test scores) versus disadvantaged backgrounds and other measures of merit and character (Bowen et al. 2005, 2009). To some extent, this is happening already, as the flagship public universities feel pressure to adjust their affirmative action admissions policies; though the Supreme Court has not yet fully struck-down race-based admissions policies, it has clearly indicated it regards them as its least preferred method of increasing diversity on campuses. ${ }^{26}$ Using family- or place-based measures of disadvantaged in place of race in admissions decisions will likely generate student bodies with somewhat lower representation of Blacks and Hispanics but higher representation of low-income and disadvantaged students of all races (Long 2004).

Of course, another way of improving the access of disadvantaged students to better-resourced colleges and universities would be to redistribute public resources more equitably between flagship and nonflagship schools. The evidence suggests that state higher education subsidies may be regressive, given the greater generosity most state legislatures show to their flagship schools (though the exact evidence depends on the range of public resources that are included in the calculations). ${ }^{27} \mathrm{Of}$ course, these legislatures tend to believe that the flagships contribute more to state

\footnotetext{
${ }^{25}$ See, for instance, the report by the Equity and Excellence Commission (U.S. Department of Education 2012b; Duncan and Murnane 2014; Chetty et al. 2011.

${ }^{26}$ In its most recent ruling on affirmative action in higher education admissions, in Fisher v. University of Texas, the Supreme Court affirmed that race could be used as one of many factors to generate a diverse student body, but only if it had exhausted all other potential remedies and found them to fail in generating such diversity.

${ }^{27}$ See Hansen and Weisbrod (1969) for the beginning of a longstanding argument on the regressive nature of state subsidies to higher education, and Johnson (2005) for evidence that these subsidies are more income-neutral when we also consider the progressive nature of the state taxes that finance them.
} 
economic development, and their alumni tend to be well represented among (or influential with) state legislators, making any such redistribution very hard to achieve.

Still, we spend nearly $\$ 200$ billion of public funds each year on higher education in America, and perhaps those funds could be spent more efficiently and generate a stronger set of academic outcomes. For one thing, a range of supports provided to improve academic outcomes are in need of some reform. These include financial aid, developmental (or remedial) education, tutoring/coaching, and the formation of learning communities.

Individual financial aid can come from the federal government in the form of Pell grants, loans, and/or work study; the institutions themselves also provide such aid. The research evidence suggests that simplicity and transparency increase student access to aid, while conditioning continuation of the aid (at least to some extent) on satisfactory academic outcomes (for example, through merit scholarships) improves performance incentives and outcomes (Dynarski and Scott-Clayton 2007; Patel et al. 2013). ${ }^{28}$ A set of Pell grant reforms have been suggested recently based on these principles (College Board 2013a; Baum and Scott-Clayton 2013). Student loans, which have recently become more burdensome to students who drop out of college or have some difficulty finding well-paying jobs after graduating, could also be made less burdensome by moving repayments to an income-contingent basis, among other reforms (Akers and Chingos 2014). ${ }^{29}$ And even providing assistance to low-income parents as they fill out financial aid forms seems to help (Bettinger et al. 2012).

The methods by which two-year and four-year colleges choose students for remediation, and then deliver it, are greatly in need of reform (Long 2014). Students are often required, for instance, to pass Algebra I, though this math is not necessary for the occupational degree in question, or they are required to pass other exams that are often shown to be unrelated to subsequent student performance in for-credit classes (Scott-Clayton 2012). ${ }^{30}$ In its current form, the provision of remediation generally has little positive effect on academic outcomes of students or even negative effects (Clotfelter et al. 2013). ${ }^{31}$

\footnotetext{
${ }^{28}$ On the other hand, Cohodes and Goodman (2014) show evidence that generous merit scholarships to in-state public university students can actually reduce the quality of the institution they attend, thus reducing college completion rates as well.

${ }^{29}$ Susan Dynarski, "What We Mean When We Say Student Debt Is Bad.” New York Times, August 8, 2014.

${ }^{30}$ While math proficiency generally and skill in algebra specifically (Holzer and Lerman 2014a) seem to contribute to one's earnings, there is much less evidence that proficiency in algebra contributes to success in completing community college or to the earnings of these students. Long (2014) argues that literacy might be more foundational for these students in terms of their ability to complete college classes.

${ }^{31}$ Negative effects might occur, for instance, if students have only limited time or financing for higher education and such time is consumed in non-credit-generating remediation rather than credit-accumulation in real courses.
} 
Accordingly, reforms that would accelerate remediation and integrate it into teaching or training classes would likely be successful (Bettinger et al. 2013). One such model, the Integrated Basic Education and Skills Training (I-BEST) program in the state of Washington, has generated strong outcomes and is regarded as a promising (though expensive) alternative to standalone remediation (Zeidenberg et al. 2010). Delivery of remediation could also be made more effective by accelerating it and better integrating it into labor market training or information.

The provision of a range of other supports - such as childcare or other income supports - can be made more accessible by programs like "Single Stop," which applies the one-stop concept of service delivery at college (often two-year) campuses. Mandatory participation of students in counseling or support classes has shown some benefits, as has "coaching" more in general (Bettinger et al. 2012). Requiring students to attend class full time while giving a generous package of income and other supports (as done in Accelerated Study in Associate Programs, or ASAP, at the City University of New York), can improve program completion rates as well (Scrivener and Weiss 2013).

\section{Expanding Postsecondary Options with Labor Market Value}

As indicated above, it is not enough just to increase college completion rates for disadvantaged students; we also need to improve the labor market value of the credentials they seek and attain.

States and regions are setting up many partnerships between community colleges and employer groups, with the hope of expanding sectoral training and career pathway programs that better connect disadvantaged workers to high-demand sectors and good-paying jobs (National Governors Association 2014). But before these efforts can replicate the best programs and achieve some real scale, some other reforms must be undertaken to address the problems of limited student information and institutional incentives described above.

On providing information, we need to undertake a major effort to improve the availability and quality of career counseling that students get. Ideally, this would begin in high school for every student. But as students approach either two- or fouryear colleges, especially in the public sector, they should obtain counseling on career pathways and job availability in their state and region as well as nationally. This counseling could be delivered through the nation's job centers (formerly called One-Stops), though now most students never set foot in them. The job centers could perhaps be expanded with satellite offices on public campuses, especially community colleges, with appropriate efforts to ensure the quality of counseling will be maintained or improved. Online data sources (such as College Measures) that provide detailed information on earnings among graduates of specific colleges could also help in this regard. 
Importantly, the data needed for such up-to-date counseling efforts are becoming more available. With federal support and encouragement, states are linking their college and labor market administrative data at the micro level and making them more accessible to researchers and policy makers (Zinn and Van Kluenen 2014). Such data could be summarized on an annual basis and presented in a manner that counselors could use to better inform student decisions, especially for those seeking an occupational credential. ${ }^{32}$

A variety of approaches could be used to improve the incentives of colleges and employers to increase job-relevant training capacity. Some of these have been incorporated in the recently reauthorized Workforce Innovation and Opportunity Act, though its capacity and budget remains quite small (National Skills Coalition 2014); and the Office of the Vice President has recently published a report on a variety of other ways of encouraging more "job driven" training (White House 2014).

In addition, I think it is important to impose some accountability through performance-driven subsidies for public colleges at the two- and even four-year level (Holzer 2014). A number of states are, in fact, beginning to do so (National Conference of State Legislatures 2014) by tying their subsidies for specific colleges to a range of student academic outcomes in a variety of ways. I would expand this approach to include postcollege employment as well as academic outcomes among the ones that determine the levels of subsidies, and with heavy weight on both sets of outcomes for disadvantaged or minority students. The federal government could also use a variety of competitive grants programs to encourage the states in this endeavor.

The administrative data described above are uniquely suited to the purpose of implementing this strategy. And there are other pitfalls that would need to be avoided-e.g., colleges would now have an incentive to "cream" or "skim" by admitting higher-quality students than before. But careful implementation of these standards, perhaps using some type of value-added measures for labor market performance among a college's enrollees and graduates (or "risk adjustment" based on their initial characteristics), could help avoid these pitfalls while we learn what really works or doesn't in this area (Bailey and Xu 2012). ${ }^{33}$

\footnotetext{
${ }^{32}$ See Jacobson (2013) for a vision of how individual students might ultimately use such data to calculate average completion rates and subsequent earnings for students like themselves at particular colleges or universities and with particular majors at each of them. At least potentially, students might be able to make much better-informed choices about colleges to attend and majors to pick using such data.

${ }^{33}$ The "Gainful Employment" regulations recently implemented by the U.S. Department of Education, on for-profit colleges and certificate programs at public ones, are another attempt to impose accountability, by focusing on debt incurred relative to incomes earned by students after college.
} 


\section{Expanding High-Quality CTE and Work-Based Learning}

High-quality career and technical education, beginning in high school and then continuing in college (through career pathway programs), could provide disadvantaged young people with a wider range of options leading to ultimate economic success. Apprenticeships and other work-based learning models could also play an important role.

The expansion of these programs, through the replicating and scaling of apparently successful models, would once again need to occur mostly at the state and local levels. A variety of states are already moving in this direction, working with major employers to increase education and training options for work in their industries. ${ }^{34}$

The federal government could, once again, play a more useful role in this process. By distributing roughly $\$ 1$ billion in funding to states and localities through the Perkins Act, the federal agencies already have a vehicle through which they can encourage the adoption of higher-quality CTE models with more universal appeal. Recently proposed reforms to Perkins (U.S. Department of Education 2012a) would help such an effort, though there is always resistance from the CTE community to implementing them. ${ }^{35}$ The Labor Department's Youth Career Connect grants could also encourage this process. And the Obama administration's recent announcement of a grants program to encourage apprenticeship (Wilson 2014) could also be the first of a number of steps to expand them as well.

\section{Conclusion}

Above I have listed a set of factors that render higher education in the U.S. less effective at helping disadvantaged students gain skills and labor market success than it otherwise might be. These factors include the weak academic preparation of poor students, the financial constraints they face, and their poor information about college options; they also include the relatively lower quality of the institutions (both two- and four-year, both for- and not-for-profit) that they attend, and the weak information about the labor markets that limit their choices, as well as the weak incentives for colleges to respond to that labor market. I then outline a set of policies and programs at the federal and state levels to improve college completion rates, labor market success for college graduates (at both the two- and four-year levels), and access to high-quality career and technical education as well as work-based learning among those students.

But a number of factors, both economic and political, could limit the effectiveness of these approaches. For one thing, a full 7 years after the beginning of the

\footnotetext{
${ }^{34}$ See Jobs for the Future (2014).

${ }^{35} \mathrm{See}$, for instance, Association of Career and Technical Education (2012).
} 
Great Recession, our nation's job market remains relatively weak, and young workers continue to show greatly reduced employment and earnings as a result (Altonji et al. 2014).$^{36}$ Because education and training are designed to prepare a more skilled supply of labor to meet employer demands, any such ongoing weakness might make these approaches less successful - especially if we train lots of individuals for jobs that they cannot get afterward. We hope that the nation's slow but steady recovery from this downturn will proceed and that its overall sluggishness will not continue to weaken the job market outcomes of young people indefinitely. ${ }^{37}$

Even if the labor market strengthens in the aggregate, labor demand now seems very dynamic and fluid across sectors of the economy. This means skills that are in high demand today might not be tomorrow as labor demand shifts (because of new technologies and globalization) often occur in unpredictable ways. Accordingly, workers trained for specific careers and sectors must also have a broad range of "portable" skills, some general and some specific, that will enable them to move between firms and sectors over time. Ongoing availability of assistance in retraining (or what some observers call "lifelong learning") as well as finding new sectors of employment should also be part of any such plan.

An ample supply of well-educated workers would hopefully also encourage employers to demand more of their labor rather than more fully automating their workplaces or sending such jobs overseas. The recent arrival of several hundred German manufacturers in the U.S. in the last few years and their expansion of production facilities here (while domestic companies continue to cut back in this area) indicates the potential for labor demand expansion if we were to generate a welltrained labor force over time ${ }^{38}$

Regardless of what policies we implement in this area, large numbers of American workers will have weak education and skills as well as low earnings over

\footnotetext{
${ }^{36}$ As of late 2014, the national unemployment rate hovers around $6 \%$. But no doubt this figure understates the degree of slack in the labor market, because many job-seekers have either dropped out of the labor force (Jared Bernstein and Harry J. Holzer. "A Win-Win Approach to Increase the Future Labor Force," PostEverything, Washington Post, September 11, 2014) and/or taken parttime jobs when they prefer full-time ones.

${ }^{37}$ Some commentators (e.g., Lawrence Summers, "On Secular Stagnation," Reuters, December 6, 2013) have suggested that the U.S. might be experiencing "secular stagnation," in which we cannot generate sufficient aggregate demand to move us back toward full employment. But Summers ("Supply Issues Could Hamper US Economy," Washington Post, September 7, 2014) and others have also worried about declines in labor force participation, perhaps partly in response to poor labor market opportunities, that occur even among those well below retirement age and which could limit potential economic growth over time. See Bernstein and Holzer (2014) for suggestions on how job training and work-based learning programs could be used to expand the earnings potential and labor force participation among these groups.

${ }^{38}$ For instance, the Siemens Corporation built a gas turbine engine manufacturing plant in North Carolina in 2012-2013, but only after it had made arrangements with local community and 4-year colleges to generate a steady stream of technicians and engineers for employment there. On the other hand, the German companies seem to come primarily because of proximity to the U.S. consumer market, low energy prices, and low regulations. We do not want to assume that any increase in the supply of skilled labor will automatically generate its own demand.
} 
time. Accordingly, increases in a range of other work supports will be necessaryincluding expansions of the earned income tax credit (EITC) for those who currently benefit very little, like childless adults and noncustodial parents; and paid parental leave. ${ }^{39}$ Moderate increases in the federal and state minimum wages could supplement these reforms (Sawhill and Karpilow 2014), ${ }^{40}$ while efforts to address a specific set of barriers in the labor market-for instance, for those with criminal records_-would be helpful as well (Council of State Governments 2013).

In addition, the nation's political and fiscal situations remain fairly bleak, especially at the federal level. Political polarization and paralysis limit federal action on almost any issue, and the combination of low taxes and very high spending on retirement programs will limit our ability to act for years (or likely decades) to come.

Yet, if we can devise policies to make our ongoing public expenditures (of nearly $\$ 200$ billion) more effective without requiring much in the way of new resources, such actions could still draw some bipartisan support. And, if federal action fails to materialize, perhaps a more practical set of executives and legislators at the state level could move ahead on this agenda.

Open Access This chapter is distributed under the terms of the Creative Commons AttributionNoncommercial 2.5 License (http://creativecommons.org/licenses/by-nc/2.5/) which permits any noncommercial use, distribution, and reproduction in any medium, provided the original author(s) and source are credited.

The images or other third party material in this chapter are included in the work's Creative Commons license, unless indicated otherwise in the credit line; if such material is not included in the work's Creative Commons license and the respective action is not permitted by statutory regulation, users will need to obtain permission from the license holder to duplicate, adapt or reproduce the material.

\section{References}

Acemoglu, Daron, and David Autor. 2010. Skills, tasks and technologies: Implications for employment and earnings. In Handbook of labor economics, vol. 4b, ed. Orley Ashenfelter and David E. Card. North Holland: Amsterdam.

Ahlstrand, Amanda, Laurie J. Bassie, and Daniel P. McMurrer. 2003. Workplace education for low-wage workers. Kalamazoo: W.E. Upjohn Institute for Employment Research.

\footnotetext{
${ }^{39}$ See MDRC (2014) for a description of this promising pilot study that increases the EITC available to childless adults in New York City. Also see Waldfogel (2007) for policy suggestions on how to expand paid leave availability for (low-income) parents.; Nelson Schwartz, "Where Factory Apprenticeship is Latest Model from Germany." New York Times, November 27, 2013.

${ }^{40}$ Economists typically fear that higher minimum wages could reduce employer demand for lowwage workers. The research evidence suggests that such effects are likely modest (or even zero), as long as they are moderate in magnitude-which means kept at $50 \%$ or below the median worker's wages (Neumark and Wascher 2009; Dube 2014). Indexing the legal minimum to either inflation or the median wage would keep it from eroding over time, though if it is indexed at a relatively high level this could also generate larger disemployment effects (Harry Holzer, "Pitfalls of Pay Increases," Washington Post, December 10, 2013).
} 
Akers, Beth, and Matthew Chingos. 2014. Is a student loan crisis on the horizon? Policy brief. Washington, DC: Brookings Institution.

Altonji, Joseph, Erica Blom, and Costas Meghir. 2012. Heterogeneity in human capital investments: High school curriculum, College majors and careers, NBER Working Paper 17985. Cambridge, MA: National Bureau of Economic Research. http://www.nber.org/papers/ w17985.

Altonji, Joseph, Lisa B. Kahn, and Jamin D. Speer. 2014. Cashier or consultant? Entry labor market conditions, field of study, and career success, NBER Working Paper 20531. Cambridge, MA: National Bureau of Economic Research. http://www.nber.org/papers/w20531.

Association for Career and Technical Education. 2012. ACTE and NASDCTEc respond to Department of Education Perkins Blueprint. Washington, DC: Association for Career and Technical Education.

Autor, David. 2014. Skills, education, and the rise of earnings inequality among the 'other 99 Percent'. Science 344(6186): 843-851.

Autor, David, Lawrence Katz, and Melissa Kearney. 2008. Trends in US wage inequality: Revising the revisionists. Review of Economics and Statistics 90(2): 300-323.

Backes, Benjamin, Harry J. Holzer, and Erin Dunlop Velez. 2014. Is it worth it? Postsecondary education and labor market outcomes for the disadvantaged, CALDER Working Paper. Washington, DC: National Center for Analysis of Longitudinal Data in Education Research, American Institutes for Research. http://www.air.org/sites/default/files/downloads/report/ Postsecondary\%20Education\%20and\%20Labor\%20Market $\% 20$ Outcomes $\% 20$ for $\% 20$ the\%20Disadvantaged_9.15.14.pdf.

Bailey, Thomas, and Clive Belfield. 2013. Community college occupation degrees: Are they worth it. In Preparing today's students for tomorrow's jobs in Metropolitan America, ed. Laura W. Perna. Philadelphia: University of Pennsylvania Press.

Bailey, Martha, and Susan Dynarski. 2011. Inequality in postsecondary education. In Whither opportunity? Rising inequality, schools, and children's life chances, ed. Greg J. Duncan and Richard Murnane. New York: Russell Sage Foundation/Spencer Foundation.

Bailey, Thomas, and Di Xu. 2012. Input-adjusted graduation rates and college accountability: What is known from twenty years of research? New York: Community College Research Center, Columbia University.

Balfanz, Robert. 2010. Building a grad nation: Progress and challenge in reducing the high school dropout epidemic. Baltimore: Johns Hopkins University.

Baum, Sandy, and Judith Scott-Clayton. 2013. Redesigning the Pell grant program for the 21st century, Policy brief. Washington, DC: The Hamilton Project, Brookings Institution.

Becker, Gary. 1996. Human capital, 2nd ed. Chicago: University of Chicago Press.

Bettinger, Eric, Bridget Terry Long, Phil Oreopoulos, and Lisa Sanbonmatsu. 2012. The role of application assistance and information in college decisions: Results from the H\&R block FAFSA experiment. Quarterly Journal of Economics 127(4): 1205-1242.

Bettinger, Eric, Angela Boatman, and Bridget Terry Long. 2013. Student supports: Developmental education and other academic programs. The Future of Children 23(1): 93-126. http://futureofchildren.org/publications/journals/article/index.xml?journalid=79andarticleid=582.

Bloom, Howard, and Rebecca Unterman. 2014. Can small schools of choice improve educational prospects for disadvantaged students? Journal of Policy Analysis and Management 33(2): 290-319.

Bound, John, Michael Lovenheim, and Sarah Turner. 2009. Why have college completion rates declined? An analysis of changing student preparation and collegiate resources, NBER Working Paper 15566. Cambridge, MA: National Bureau of Economic Research. http://www. nber.org/papers/w15566.

Bowen, William, Martin Kurzweil, and Eugene Tobin. 2005. Equity and excellence in American higher education. Charlottesville: University of Virginia Press.

Bowen, William, Matthew Chingos, and Michael McPherson. 2009. Crossing the finish line: Completion at America's public colleges. Princeton: Princeton University Press. 
Brown, Meta, John Karl Scholz, and Ananth Seshadri. 2009. A new test of borrowing constraints in education, NBER Working Paper 14879. Cambridge, MA: National Bureau of Economic Research. http://www.nber.org/papers/w14879.

Card, David, and Jonathan Dinardo. 2007. The impact of technological change on low-wage workers: A review. In Working and poor, ed. Rebecca M. Blank, Sheldon Danziger, and Robert F. Schoeni. New York: Russell Sage.

Carnevale, Anthony, Nicole Smith, and Jeff Strohl. 2011. Help wanted: Projections of jobs and education requirements through 2018. Washington, DC: Center for Education and the Workforce, Georgetown University.

Cellini, Stephanie. 2012. For-profit higher education: An assessment of costs and benefits. National Tax Journal 65(1): 153-180.

Chetty, Raj, John N. Friedman, and Jonah E. Rockoff. 2011. The long-term impacts of teachers: Teacher value-added and student incomes in adulthood, NBER Working Paper 17699. Cambridge, MA: National Bureau of Economic Research. http://www.nber.org/papers/ w17699.pdf.

CLASP (Center for Law and Social Policy). 2014. Shared vision, strong systems: The alliance for quality career pathways framework version 1.0. Washington, DC: CLASP. http://www.clasp. org/issues/postsecondary/pages/aqcp-framework-version-1-0.

Clotfelter, Charles, Helen F. Ladd, Clara Muschkin, and Jacob L. Vigdor. 2013. Developmental education in North Carolina community colleges, CALDER Working Paper. Washington, DC: National Center for Analysis of Longitudinal Data in Education Research, American Institutes for Research, American Institutes for Research.

Cohodes, Sarah, and Joshua Goodman. 2014. Merit aid, college quality, and college completion: Massachusetts' Adams scholarship as an in-kind subsidy. American Economic Journal: Applied Economics 6(4): 251-285.

College Board. 2013a. Rethinking Pell grants. Washington, DC: College Board.

College Board. 2013b. Trends in student aid. Washington, DC: College Board.

College Measures. www.collegemeasures.org. Accessed 20 Sept 2014.

Council of State Governments Justice Center. 2013. Integrated reentry and employment strategies: Reducing recidivism and promoting job readiness. Washington, DC: Council of State Governments Justice Center. https://www.bja.gov/Publications/CSG-Reentry-andEmployment.pdf.

Deming, David, Claudia Goldin, and Lawrence Katz. 2013. For-profit colleges. The Future of Children 23(1): 137-163.

Dube, Arin. 2014. Designing thoughtful minimum wage policies at the state and local levels. In Kearney, Harris, and Anderson 2014.

Duncan, Greg, and Richard Murnane. 2014. Restoring opportunity. New York: Russell Sage.

Dynarski, Susan, and Judith Scott-Clayton. 2007. College grants on a postcard: A proposal for simple and predictable federal student aid. Washington, DC: Hamilton Project, Brookings Institution.

Fein, David, Howard Rolston, David Judkins, and Karen N. Gardiner. 2013. Learning what works in career pathways: The ISIS evaluation. Paper presented at the Association of Public Policy and Management Annual Research Conference, Washington, DC.

Freeman, Richard. 1971. The market for college-trained manpower. Cambridge, MA: Harvard University Press.

Freeman, Richard. 1976. The over-educated American. Cambridge, MA: Harvard University Press.

Goldin, Claudia, and Lawrence F. Katz. 2008. The race between education and technology. Cambridge, MA: Harvard University Press.

Goodman, Sarena. 2013. Learning from the test: Raising selective college enrollment by providing information. Washington, DC: Board of Governors, Federal Reserve Bank.

Hansen, W. Lee, and Burton Weisbrod. 1969. The distribution of costs and direct benefits of public higher education: The case of California. The Journal of Human Resources 4(2): 176-191. 
Heckman, James, John Humphries, and Nicholas Mader. 2010. The GED, NBER Working Paper 16064. Cambridge, MA: National Bureau of Economic Research Working Paper.

Hoffman, Nancy. 2011. Schooling in the workplace. Cambridge, MA: Harvard Education Press.

Hollenbeck, Kevin. 2008. Is there a role for public support of incumbent workers on-the-Job training? Working Paper 08-138. Kalamazoo: W. E. Upjohn Institute for Employment Research.

Holzer, Harry. 2014. Improving education and employment outcomes for disadvantaged students. In Kearney, Harris, and Anderson 2014.

Holzer, Harry, and Erin Dunlop. 2013. Just the facts Ma'am: Postsecondary education and labor market outcomes in the US, CALDER Working Paper. Washington, DC: National Center for Analysis of Longitudinal Data in Education Research, American Institutes for Research.

Holzer, Harry, and Robert Lerman. 2014a. Cognitive skills in the US labor market: For whom do they matter? Prepared for conference on PIAAC. Washington, DC: American Institutes for Research.

Holzer, Harry, and Robert Lerman 2014b. Work-based learning for youth. Challenge (July-August).

Holzer, Harry, and David Neumark. 2006. Affirmative action: What do we know? Journal of Policy Analysis and Management 25 (2).

Holzer, Harry, Richard N. Block, Marcus Cheatham, and Jack H. Knott. 1993. Are training subsidies for firms effective? The Michigan experience. Industrial and Labor Relations Review 46(4): 625-636.

Holzer, Harry, Dane Linn, and Wanda Monthey. 2013. The promise of high-quality career and technical education. Washington, DC: The College Board.

Hoxby, Caroline, and Sarah Turner. 2014. Expanding college opportunities for high-Achieving, low income students, SIEPR Discussion Paper 12-014. Stanford: Stanford Institute for Economic Policy Research.

Hyman, Joshua. 2013. ACT for all: The effect of mandatory college entrance exams on postsecondary attainment and choice, Working Paper. Ann Arbor: University of Michigan.

Jacobson, Louis. 2013. Using data to improve the performance of workforce training. Washington, DC: The Hamilton Project, Brookings Institution.

Jenkins, Davis, and Sung-Woo Cho. 2012. Get with the program: Accelerating community college students entry into and completion of programs of study, Working paper. New York: Community College Research Center, Columbia University.

Jobs for the Future. 2014. Pathways to prosperity network: State progress report. Boston: Jobs for the Future.

Johnson, William. 2005. Are public subsidies to higher education regressive? Unpublished paper, University of Virginia.

Kane, Thomas, and Cecelia Rouse. 1995. Labor market returns to two-year and four-year colleges. American Economic Review 85(3).

Kearney, Melissa S., Benjamin H. Harris, and Karen L. Anderson (eds.). 2014. Policies to address poverty in America (June). Washington, DC: Hamilton, Project, Brookings Institution.

Kemple, James. 2008. Career academies: Long-term impacts on work, education and transitions to adulthood. New York: MDRC.

Lerman, Robert. 2014. Expanding apprenticeship opportunities in America. In Kearney, Harris, and Anderson 2014.

Long, Mark. 2004. Race and college admissions: An alternative to affirmative action? Review of Economics and Statistics 86(4): 1020-1037.

Long, Bridget Terry. 2014. Addressing the academic barriers to success in higher education. In Kearney, Harris, and Anderson 2014.

Long, Mark C., Dan Goldhaber, and Nick Huntington-Klein. 2014. Do student college major choices respond to changes in wages? Paper presented at National Center for Analysis of Longitudinal Data in Education Research (CALDER) Research Conference, American Institutes of Research, Washington, DC (February).

Lovenheim, Michael. 2011. The effect of liquid housing wealth on college enrollment. Journal of Labor Economics 29(4): 370-422. 
Magnuson, Katherine, and Jane Waldfogel (eds.). 2008. Steady gains and stalled progress: Inequality and the Black-White test score Gap. New York: Russell Sage.

Maguire, Sheila, Joshua Freely, Carol Clymer, Maureen Conway, and Deena Schwartz. 2010. Tuning into local labor markets. Philadelphia: PPV.

MDRC. 2014. Paycheck plus: Making work pay for Low-income single adults, Policy brief. New York: MDRC.

Mincer, Jacob. 1974. Education, experience and earnings. Chicago: University of Chicago Press.

Mishel, Lawrence, Josh Bivens, Elise Gould, and Heidi Shierholz. 2012-2013. The state of working America, 12th Ed. Ithaca: Cornell University Press.

Murnane, Richard. 2013. US high school graduation rates: Patterns and explanations. Journal of Economic Literature 51(2): 370-422.

Murnane, Richard, and John Tyler. 2000. Who benefits from obtaining a GED? Evidence from high school and beyond. Review of Economics and Statistics 82(1): 23-37.

National Conference of State Legislatures. 2014. Performance-based funding for higher education. http://www.ncsl.org/research/education/performance-funding.aspx.

National Fund for Workforce Solutions. www.nfwsolutions.org. Accessed 17 Sept 2014.

National Governors Association Center for Best Practices. 2014. State sector strategies coming of age: Implications for state workforce policymakers. Washington, DC: NGA Center for Best Practices.

National Skills Coalition. Federal policy: Workforce innovation and opportunity Act. http://www. nationalskillscoalition.org/federal-policy/workforce-investment-act. Accessed 17 Sept 2014.

Neumark, David. 2007. Improving school-to-work transitions. New York: Russell Sage.

Neumark, David, and William Wascher. 2009. Minimum wages. Cambridge, MA: MIT Press.

OECD (Organisation for Economic Co-operation and Development). 2013. OECD Skills Outlook 2013. Paris: OECD Publishing. http://skills.oecd.org/skillsoutlook.html.

Owen, Stephanie, and Isabel Sawhill. 2013. Should everyone go to college? Policy brief. Washington, DC: Brookings Institution.

Page, Lindsay. 2012. Understanding the impact of career academy attendance: An application of the principal stratification framework for causal effects accounting for partial compliance. Evaluation Review 36(2): 99-132.

Patel, Reshma, Lashawn Richburg-Hayes, Elijah de la Campa, and Timothy Rudd. 2013. Performance-based scholarships: What have we learned? New York: MDRC.

Reardon, Sean F. 2011. The widening achievement gap between the rich and the poor: New evidence and possible explanations. In Whither opportunity: Rising inequality, schools, and children's life chances, ed. Greg J. Duncan and Richard J. Murnane, 91-116. New York: Russell Sage Foundation/Spencer Foundation.

Roder, Anne, and Mark Elliott. 2011. A promising start: Initial impacts of year up on low-income students careers. New York: Economic Mobility Corporation.

Rosenbaum, James. 2001. Beyond college for all: Career paths for the forgotten half. New York: Russell Sage.

Rosenbaum, James. 2002. Beyond college for all. New York: Russell Sage.

Sacerdote, Bruce. 2001. Peer effects with random assignment: Results for Dartmouth roommates. Quarterly Journal of Economics 116(2): 684-704.

Sawhill, Isabel, and Quentin Karpilow. 2014. A no-cost proposal to reduce poverty and inequality, Center for Children and Families policy brief. Washington, DC: Brookings Institution.

Schwartz, Robert, and Nancy Hoffman. 2014. Career pathways: A route to upward mobility. Paper presented at the Conference on Education for Improving Mobility, Thomas B. Fordham Institute, New York.

Scott-Clayton, Judith. 2011. The shapeless river: Does a lack of structure inhibit student progress at community colleges? Working paper. New York: Community College Research Center, Columbia University.

Scott-Clayton, Judith. 2012. Do high-stakes placement exams predict college success? Working paper. New York: Community College Research Center, Columbia University. 
Scrivener, Susan, and Michael Weiss. 2013. More graduates: Two-year results from an evaluation of accelerated study in associates programs (ASAP) for developmental education students. New York: MDRC.

Symonds, William, Robert Schwartz, and Ronald Ferguson. 2011. Pathways to prosperity: Meeting the challenge of preparing young Americans for the 21st century. Cambridge, MA: Graduate School of Education, Harvard University.

U.S. Department of Education. 2012a. Investing in America's future: A blueprint for transforming career and technical education. Washington, DC. http://www.ed.gov/news/speeches/ investing-americas-future-blueprint-transforming-career-and-technical-education.

U.S. Department of Education. 2012b. For each and every child: A strategy for achieving equity and excellence in education. Report by the Commission on Equity and Excellence. Washington, DC.

Waldfogel, Jane. 2007. Work-family policies. In Reshaping the American workforce in a changing economy, ed. Harry Holzer and Demetra S. Nightingale. Washington, DC: Urban Institute Press.

White House. 2014. Ready to work: Job-driven training and American opportunity. Washington, DC.

Wilson, Scott. 2014. Obama announces $\$ 600 \mathrm{M}$ in grants programs to prepare workers for jobs. Washington Post, April 16.

Wiswall, Matthew, and Basit Zafar. 2013. How do college students respond to public information about earnings? Staff Reports 516. New York: Federal Reserve Bank.

Zeidenberg, Matthew, Sung-Woo Cho, and Davis Jenkins. 2010. Washington State's integrated basic education and skills training (I-BEST) program: New evidence of effectiveness, Working Paper. New York: Community College Research Center, Columbia University. http://ccrc. tc.columbia.edu/publications/i-best-new-evidence.html.

Zinn, Rachel, and Andy Van Kluenen. 2014. Making workforce data work. Washington, DC: Workforce Data Quality Campaign. 